\title{
Animal model studies on viral infections
}

\author{
Akio Adachi ${ }^{1 *}$ and Tomoyuki Miura ${ }^{2}$ \\ ${ }^{1}$ Department of Microbiology, Institute of Health Biosciences, The University of Tokushima Graduate School, Tokushima, Japan \\ ${ }^{2}$ Laboratory of Primate Model, Experimental Research Center for Infectious Diseases, Institute for Virus Research, Kyoto University, Kyoto, Japan \\ *Correspondence: adachi@basic.med.tokushima-u.ac.jp
}

Edited by:

Akihide Ryo, Yokohama City University, Japan

Reviewed by:

Yasuo Ariumi, Kumamoto University, Japan

Ayumi Kudoh, Yokohama City University School of Medicine, Japan

Keywords: animal models, viral infections, viral replication, viral pathogenicity, anti-viral strategies

One of the major missions of animal virology is to understand how viruses replicate and cause asymptomatic/symptomatic conditions in individuals (Nomaguchi and Adachi, 2010). It is especially important for virologists who work on viruses pathogenic for humans to elucidate bases underlying the in vivo viral characteristics. Toward this end, animal model studies in some ways are necessary to precisely analyze the in vivo situation, and also are essential for developing countermeasures against virus infections. Since a full variety of viruses with distinct biological properties exist, we virologists should study "the target virus" in a specialized manner, in addition to common theoretical/experimental approaches. The Research Topic entitled "Animal model studies on viral infections" collects articles that describe the studies on numerous virus species for their animal models, or those at various stages toward animal experiments.

Articles in this Research Topic were written by experts in various research fields, and can be fairly grouped into a few categories: (i) descriptions/evaluations/new challenges of animal model studies for investigating the biology of viruses; (ii) experimental materials/methods for upcoming animal model studies; (iii) observations important for animal model studies. (i) Reynaud and Horvat (2013) have described the animal models for human herpesvirus 6 to better understand its pathogenic property. Studies on filoviruses, classified as biosafety level- 4 and represent a serious world-wide problem today, have been reviewed by Nakayama and Saijo (2013). Mailly et al. (2013) have focused on the quest for appropriate animal models for hepatitis C virus. Clark et al. (2013) have discussed about the use of nonhuman primates as models for dengue hemorrhagic fever/dengue shock syndrome. Ohsugi (2013) has summarized mouse strains transgenic for the tax gene of human T-cell leukemia virus type 1 (HTLV-1). Also, a bovine model for HTLV-1 pathogenesis has been described by Aida et al. (2013). Challenging new attempts to establish human immunodeficiency virus type 1 (HIV-1)/macaque infection models have been reviewed by Misra et al. (2013), and also by Saito and Akari (2013). Another approach to understand HIV-1 biology in vivo has been described by Matsuyama-Murata et al. (2013). (ii) Kodama et al. (2013) has described a new and simple method to prepare human dendritic cells from peripheral blood mononuclear cells. Doi et al. (2013) have summarized their studies on macaque-tropic HIV-1 clones.
Ikeno et al. (2013) has reported a new, sensitive, and quantitative system to monitor measles virus infection in humanized mice. Iwami et al. (2013) have summarized the quantification of viral infection dynamics based on various quantitative analyses. (iii) Tada et al. (2013) have suggested that LEDGF/p75 may be a cellular factor acting as a species-barrier against HIV-1 in mouse cells. Kuwata et al. (2013) have shown that simian immunodeficiency virus may acquire the increased infectivity and resistance to neutralizing antibodies by truncation of its gp 41 cytoplasmic tail. Ohsugi et al. (2013) have reported that natural infection status of laboratory mice by murine norovirus. Finally, Kajitani et al. (2013) have described the possible involvement of $\mathrm{E} 1^{\wedge} \mathrm{E} 4$ protein of human papillomavirus type 18 in its differentiation-dependent life cycle.

We are proud to add our "Animal model studies on viral infections" to a series of Research Topic in Frontiers in Microbiology. A wide variety of DNA and RNA viruses are covered by this special issue consisting of original research, review, mini-review, methods, and opinion articles. As we described in the beginning, animal studies are certainly required for understanding virus replicative/pathogenic properties in vivo and for overcoming virally-caused infectious diseases. We human virologists should make every effort to fight against numbers of unique pathogenic viruses.

\section{REFERENCES}

Aida, Y., Murakami, H., Takagashi, M., and Takeshima, S. (2013). Mechanisms of pathogenesis induced by bovine leukemia virus as a model for huma T-cell leukemia virus. Front. Microbiol. 4:328. doi: 10.3389/fmicb.2013.00328

Clark, K., Onlamoon, N., Hsiao, H.-M., Perng, G., and Villinger, F. (2013). Can non-huma primates serve as models for investigating dengue disease pathogenesis? Front. Microbiol. 4:305. doi: 10.3389/fmicb.2013.00305

Doi, N., Okubo, A., Yamane, M., Sakai, Y., Adachi, A., and Nomaguchi, M. (2013). Growth potentials of CCR5-tropic/CXCR4-tropic HIV-1mt clones in macaque cells. Front. Microbiol. 4:2188. doi: 10.3389/fmicb.2013.00218

Ikeno, S., Suzuki, M., Muhsen, M., Ishige, M., Kobayashi, M., Ohno, S., et al. (2013). Sensitive detection of measles virus infection in the blood and tissues of humanized mouse by one-step quantitative RT-PCR. Front. Microbiol. 4:298. doi: 10.3389/fmicb.2013.00298

Iwami, S., Koizumi, Y., Ikeda, H., and Kakizoe, Y. (2013). Quantification of viral infection dynamics in animal experiments. Front. Microbiol. 4:264. doi: 10.3389/fmicb.2013.002264

Kajitani, N., Satsuka, A., Yoshida, S., and Sakai, K. (2013). HPV 18 E1 ${ }^{\wedge}$ E4 is assembled into aggresome-like compartment and involved in sequestration 
of viral oncoproteins. Front. Microbiol. 4:251. doi: 10.3389/fmicb.2013. 00251

Kodama, A., Tanaka, R., Saito, M., Ansari, A., and Tanaka, Y. (2013). A novel and simple method for generation of human dendritic cells from unfractionated peripheral blood mononuclear cells within 2 days: its application for induction of HIV-1-reactive CD4 ${ }^{+}$T cells in the hu-PBL SCID mice. Front. Microbiol. 4:292. doi: $10.3389 /$ fmicb.2013.00292

Kuwata, T., Takaki, K., Enomoto, I., Yoshimura, K., and Matsushita, S. (2013). Increased infectivity in human cells and resistance to antibody-mediated neutralization by truncation of the SIV gp41 cytoplasmic tail. Front. Microbiol. 4:117. doi: $10.3389 /$ fmicb.2013.00117

Mailly, L., Robinet, E., Meuleman, P., Baumert, T. F., and Zeisel, M. B. (2013). Hepatitis C virus infection and related liver disease: the quest for the best animal model. Front. Microbiol. 4:212. doi: 10.3389/fmicb.2013. 00212

Matsuyama-Murata, M., Inaba, K., Horiuchi, R., Fukazawa, Y., Ibuki, K., Hayami, M., et al. (2013). Genetic similarity of circulating and small intestinal virus at the end stage of acute pathogenic simian-human immunodeficiency virus infection. Front. Microbiol. 4:204. doi: 10.3389/fmicb.2013.00204

Misra, A., Thippeshappa, R., and Kimata, J. T. (2013). Macaques as model hosts for studies of HIV-1 infection. Front. Microbiol. 4:176. doi: $10.3389 /$ fmicb. 2013.00176

Nakayama, E., and Saijo, M. (2013). Animal models for Ebola and Marburg virus infections. Front. Microbiol. 4:267. doi: 10.3389/fmicb.2013.00267

Nomaguchi, M., and Adachi, A. (2010). Virology as biosystematics: towards understanding the viral infection biology. Front. Microbiol. 1:2. doi: 10.3389/fmicb. 2010.00002

Ohsugi, T. (2013). A transgenic mouse model of huma T cell leukemia virus type 1-associated diseases. Front. Microbiol. 4:49. doi: 10.3389/fmicb.2013. 00049
Ohsugi, T., Matsuura, K., Kawabe, S., Nakamura, N., Kumar, J. M., Wakamiya, M., et al. (2013). Natural infection of murine norovirus in conventional and specific pathogen-free laboratory mice. Front. Microbiol. 4:12. doi: 10.3389/fmicb.2013.00012

Reynaud, J., and Horvat, B. (2013). Animal models for human herpesvirus 6 infection. Front. Microbiol. 4:174. doi: 10.3389/fmicb.2013.00174

Saito, A., and Akari, H. (2013). Macaque-tropic human immunodeficiency virus type 1: breaking out of the host restriction factors. Front. Microbiol. 4:187. doi: 10.3389/fmicb.2013.00187

Tada, T., Kadoki, M., Yang, L., Tokunaga, K., and Iwakura, Y. (2013). Transgenic expression of the human LEDGF/p75 gene relieves the species barrier against HIV-1 infection in mouse cells. Front. Microbiol. 4:377. doi: $10.3389 /$ fmicb. 2013.00377

Conflict of Interest Statement: The authors declare that the research was conducted in the absence of any commercial or financial relationships that could be construed as a potential conflict of interest.

Received: 03 November 2014; accepted: 19 November 2014; published online: 03 December 2014.

Citation: Adachi A and Miura T (2014) Animal model studies on viral infections. Front. Microbiol. 5:672. doi: 10.3389/fmicb.2014.00672

This article was submitted to Virology, a section of the journal Frontiers in Microbiology.

Copyright (c) 2014 Adachi and Miura. This is an open-access article distributed under the terms of the Creative Commons Attribution License (CC BY). The use, distribution or reproduction in other forums is permitted, provided the original author(s) or licensor are credited and that the original publication in this journal is cited, in accordance with accepted academic practice. No use, distribution or reproduction is permitted which does not comply with these terms. 